\title{
Microbial xylanases and their inhibition by specific proteins in cereals
}

\author{
Daniela Chmelová, Dominika Škulcová, Miroslav Ondrejovič \\ Department of Biotechnology, Faculty of Natural Sciences, Univer- \\ sity of Ss. Cyril and Methodius in Trnava, Nám. J. Herdu 2, \\ SK - 917 01, Slovakia \\ * Corresponding author: daniela.chmelova@ucm.sk
}

\begin{abstract}
Arabinoxylans (AXs) belong to the components of plant cells which are mainly degraded by microbial xylanases during colonization of grain by phytopathogens. For the defence, cereals contain proteinaceous xylanase inhibitors (XIs), namely xylanase inhibitor protein (XIP), Triticum aestivum xylanase inhibitor (TAXI) and thaumatin-like xylanase inhibitor (TLXI). Their presence in cereals in high levels can be a serious problem in different industrial applications. XIs regulate $A X$ hydrolysis and participate in plant defence mechanisms. XIs have various specificity against microbial xylanases from the glycoside hydrolase (GH) families of GH10 and GH11. Therefore, this review brings new information about the function of XIs as defence responses to pathogen infection of plants and as a problem in plant material processing in different industrial applications.
\end{abstract}

Key words: xylanase inhibitor, cereals, plant defence, xylanases.

\section{Introduction}

Arabinoxylans (AXs) and glucans are non-starch polysaccharides present in cereal grains and these cell wall components were also confirmed in barley (Egi et al., 2004). AXs are mainly presented in the cell wall of aleurone tissues, half of AXs in barley grains is located in the husk and a significant content of AXs was found in the endosperm walls (60-70\%) (Saulnier et al., 2007). They are hydrolysed by xylanases, namely endo-(1-4)- $\beta$-xylanases (EC 3.2.1.8), $\beta$-D-xylosidases (EC 3.2.1.37), and $\alpha$-L-arabinofuranosidases (Goesaert et al., 2001). The majority of xylanases degrading AXs are produced by microbial contaminates of barley grains. For the regulation of their activity, cereals produce their own xylanases in the form of the xylanase precursor in the aleurone cells (Caspers et al., 2001; Simpson et al., 2003; Selvaraj et al., 2010) and xylanase inhibitors (XIs) controlling the AX hydrolysis and the utilization of starchy resources (Caspers et al., 2001; Evers and Millar, 2002). These processes play the key role in the natural defence to disease (Payan et al., 2004; Dornez et al., 2010; Zhan et al., 2017a; Sun et al., 2018).
More than $90 \%$ of total xylanase activity in cereals has a microbial origin (Dornez et al., 2008). Microbial xylanases are included in the glycoside hydrolase (GH) family, specifically GH10 and GH11 families (Simpson et al., 2003). Generally, the GH10 xylanases have higher molecular weights ( $>30 \mathrm{kDa}$ ) than xylanases of the GH11 family $(\sim 20 \mathrm{kDa})$. Microbial xylanases are produced by bacteria and fungi (Fusarium graminearum, Botrytis cinerea, Magnaporthe grisea and Aspergillus fumigatus) and ensure the release of nutrients from the outer kernel layers of barley grains. Some of these organisms such Aspergillus sp. and Trichoderma sp. have been used for industrial production of xylanases resulting of the improval of end-product quality (Wu et al., 1997; Brutus et al., 2005; Paper et al., 2007). Generally, microbial xylanase activity is significantly affected by proteinaceous XIs. These proteins have various specificities and were detected in seed endosperm and bran (Rouau and Surget, 1998). XIs are specified for xylanases produced by microorganisms and the inhibition of endogenous plant xylanases was not observed (Hou et al., 2013). 
Levels of XIs can be a serious problem in different industrial applications in which the addition of exogenous xylanases affects the final quality of products (Dornez et al., 2011; Smeets et al., 2014). The high content of XIs in certain cereals reduces the xylanase efficiency in bread making, and a higher enzyme dosage should be used (Dornez et al., 2011). The supplementation of xylanases in broiler feeds is commonly used to improve feed digestion. Krogh Madsen et al. (2018) observed that broilers fed with wheat containing the highest xylanase inhibitory activity resulted in the lowest growth rates. Inhibitory activity of these proteins was not affected during the digestion process, and feed pelleting at $85^{\circ} \mathrm{C}$ had no effect on their activity (Smeets et al., 2014). Similarly, xylanase inhibition makes a problem in the processing of cereals including malting and brewing (Dornez et al., 2009), gluten-strach separation (Frederix et al., 2004) and refrigerated dough (Simsek and Ohm, 2009).

Therefore, the aim of this study was to describe the function of XIs against xylanases of the GH10 and GH11 families and defence responses to pathogen infection of plants.

\section{Xylanase inhibitors}

XIs are involved in the development and germination of the cereal grains (Gebruers et al., 2004; Croes et al., 2009a). The well-known inhibitors of microbial xylanases are xylanase inhibitor protein (XIP), Triticum aestivum xylanase inhibitor (TAXI) and thaumatin-like xylanase inhibitor (TLXI) (Debyser et al., 1997; McLauchlan et al., 1999; Fierens et al., 2007). Lin et al. (2013) described the fourth type of xylanase inhibitor, XILP (xylanase inhibitor-like protein), homologous to XIs from wheat and rice, but the molecular weight of XILP is lower than that of wheat and rice inhibitors. XILP inhibits fungal xylanases and exhibits antifungal activities, inhibits proliferation of various cancer cell lines and reduces HIV-1 reverse transcriptase.

The content of XIP, TAXI and TLXI in cereals varies. The content of XIP varied from 0.12 to $0.6 \mathrm{mg} / \mathrm{g}$ plant material, TAXI content ranges from 0.05 to $0.3 \mathrm{mg} / \mathrm{g}$ plant material (Bonnin et al., 2005; Dornez et al., 2006; Croes et al., 2009a) and the content of TLXI varied from 0.51 to 1.50 (Croes et al., 2009a). TAXI and XIP proteins are mainly located in the outer layers of grains (Mendis et al., 2013). TLXI was almost exclusively found in seeds of cereals while the presence of XIP and TAXI was also observed in roots and shoots of the growing seedlings. Moreover, the highest XI levels were observed at later stages of maturation. This finding suggests that these proteins can play a role in the growth and development of plants. A signif- icant loss of inhibitor signals was observed in fourth day of germination (Croes et al., 2009b). Also, XIs exhibit different effectiveness against bacterial and fungal xylanases and also differ from each other by the mechanism of enzyme inhibition (Gebruers et al., 2001; Flatman et al., 2002; Dornez et al., 2010; Gusakov, 2010).

\subsection{Xylanase inhibitor protein (XIP)}

XIP is an extracellular protein isolated for the first time from wheat (Triticum aestivum var. Soisson) flour (McLauchlan et al., 1999) and belongs to the best-characterized XIs. XIPs are usually glycosylated monomeric basic proteins with the average molecular weight of $30 \mathrm{kDa}$ and with $\mathrm{pI}$ values in the range from 7.0 to 9.0 (McLauchlan et al., 1999; Elliot et al., 2002; Juge et al., 2004). This plant-derived protein has been shown to inhibit fungal endo- $\beta$ - $(1,4)$-xylanases belonging to the GH10 and GH11 families (Flatman et al., 2002). Also, it has been reported that XIP does not inhibit both bacterial and endogenous plant xylanases (Juge et al., 2004). XIP from wheat has biochemical properties similar to XIP-type inhibitors from other cereals.

XIP exists in different isoforms; Gebruers et al. (2002) identified the presence of five XIP-I isoforms. The presence of various XIP variants can be affected by a modification during the storage of cereals, the purification of these proteins or can be the results of post-translational modifications (glycosylation), or is the product of multiple xip genes (McLauchlan et al., 1999; Flatman et al., 2002). Homologous fragments to xip-I gene were found in barley, rye and corn while homologous fragments to xip-II and xip-III genes were only shown in rice and sorghum (Goesaert et al., 2004). Four XIP-type inhibitors have been reported in rice, namely rice XIP, RIXI, OsXIP and OsHI-XIP (Zhan et al., 2017a). Twenty homologous xip genes called xip- $R$ gene family were identified in the roots of hexaploid wheat (Takahashi-Ando et al., 2007). XIP-Is were identified in four plant species, including sorghum, rice, maize and Brachypodium (Sonah et al., 2016). These authors also found that the xip genes generally have few or no introns, and about $75 \%$ of total xip-I genes identified in cereals are without introns.

XIP-I is encoded by a xip-I gene and is related to chitinases of the family GH18 (Sonah et al., 2016). XIP-I shows no chitinase activity. Juge et al. (2004) suggested that insufficient chitinase activity can be caused by the XIP-I binding cleft. Xip-I gene encodes 274 amino acids. The signal peptide forms 30 of these amino acids (Elliot et al., 2002). XIP-I molecule consists of $(\beta / \alpha)_{8}$-barrel fold (Terwisscha van Scheltinga et al., 1996). This inhibitor contains two conventional regions and two non-proline cis-peptide bonds, namely Ser-36-Phe and Trp-256-Asp (Terwisscha van Scheltinga et al., 1996; Drouillard et al., 
1997). Using the 3D structure of XIP-I in complexes with Aspergillus nidulans xylanase (GH10) and Penicillium funiculosum xylanase (GH11), XIP-I have been shown to have two independent binding sites. One of them specifically interacts with xylanases of the GH10 family and another with xylanases of the GH11 family. The insertion of an XIP-I П-shaped loop into the enzyme active site causes the inhibition of GH11 xylanases whereas the residues in the helix $\alpha 7$ of XIP-I mediate the reversible inhibition of GH10 xylanase (Payan et al., 2004).

The specificity of XIPs was determined against various bacterial and fungal xylanases from the GH10 and GH11 families (Flatman et al., 2002; Furniss et al., 2002; Chang et al., 2016). Structural analyses of XIP-I suggest that this protein is able to interact with GH10 and GH11 xylanases of bacterial and fungal origins (Payan et al., 2004). Indeed, all tested fungal xylanases were inhibited by XIP-I, except for xylanase from Aspergillus aculeatus belonging to the GH10 family. XIP-I inhibition was competitive for all tested xylanases, indicating the protein binding near or directly at the active site (Flatman et al., 2002; Furniss et al., 2002). XIP-I did not inhibit bacterial xylanases (Flatman et al., 2002). XIP-I recognizes the difference between bacterial and fungal xylanases belonging to the same GH family. This specificity is a unique property of XIP (Gebruers et al., 2001). XIP-I is also able to inhibit certain $\alpha$-amylases from the GH13 family and this dual inhibitory function of XIP-I can be potentially important for biotechnological applications (Sancho et al., 2003; Juge et al., 2004). Also, XIP-II shows inhibition against the fungal GH11 xylanases (Elliot et al., 2009).

In addition, the preparation of recombinant XIP was also investigated (Elliot et al., 2002; Takahashi-Ando et al., 2007; Liu et al., 2017). XIP-I protein was expressed in Escherichia coli and was then able to inhibit endo-1,4- $\beta$-D-xylanase activity. The recombinant protein rapidly lost its biological activity. This could be caused by insufficient or incomplete glycosylation (Elliot et al., 2002). Also, recombinant XIP-R protein isolated from hexaploid wheat was expressed in $E$. coli without the loss of biological activity (Takahashi-Ando et al., 2007). XIP identified in rice (RIXI, rice xylanase inhibitor) was expressed in E. coli (reERIXI) and this protein inhibited fungal GH11 xylanases (Huo et al., 2018). Surprisingly, recombinant RIXI inhibited both fungal and bacterial xylanases (Hou et al., 2013; Huo et al., 2018). Liu et al. (2017) observed that recombinant XIP inhibited xylanase from the rumen bacterium Paenibacillus sp. This xylanase has five highly conserved amino acids which can be the key residues in the interaction of XIP with xylanase (Payan et al., 2004; Liu et al., 2017). The inhibition of bacterial xylanases by XIPs was only observed within recombinantly prepared XIP, no native XIPs could inhibit bacterial xylanases.

Two XIP proteins were also expressed by Pichia pastoris. Although overglycosylation of XIP recombinant proteins was observed, inhibitory activity was not affected and both recombinant XIPs inhibited xylanases of the GH10 and GH11 families (Liu et al., 2017). P. pastoris and E. coli were also used by Hou et al. (2013) for recombinant RIXI protein production. The level of xylanase inhibitory activities and molecular weight of recombinant RIXIs were similar but $E$. coli is more suitable for recombinant production due to the production rate and costs.

The presence of XIPs in plants could be caused by their evolution as part of plant pathogen protection, predominantly against fungal pathogens (Zhan et al., 2017a). The expression of XIPs was also associated with stress-induced factors, namely herbivore infestation, mechanical wounding or the presence of methyl jasmonate, and caused the accumulation of XIPs in roots and partially in shoots. It has been assumed that XIP production is involved in plant defence responses via methyl jasmonate signal pathway (Zhan et al., 2017a; Zhan et al., 2017b). Payan et al. (2004), Takahashi-Ando et al. (2007) and Sun et al. (2018) similarly reported that XIPs are involved in plant defence against a pathogen and are probably overexpressed in plant as the response to pathogen attack. The production of XIP-I can prevent cell death and could limit F. graminearum infection via the inhibition of xylanase activity (Tundo et al., 2015). Osxip expression in transgenic plants was mainly observed in the shoot and root tissues after the exposure of two-week-old seedlings of rice to Nilaparvata lugens (Sun et al., 2018). Some researchers suggest that transgenic plants with over-expression of XIP may be more resistant to pathogens than wild-type plants (Hou et al., 2014; Tundo et al., 2015; Zhan et al., 2017a).

\subsection{Triticum aestivum xylanase inhibitor (TAXI)}

TAXI protein inhibitors were discovered and described in 1997 (Debyser et al., 1997). TAXI is a $40 \mathrm{kDa}$ polypeptide (Gebruers et al., 2001). TAXI consists from two different proteins, namely TAXI-I and TAXI-II with $86 \%$ sequence identity. These types of TAXI are differ in N-terminal amino acid end and their inhibitory specificity (Gebruers et al., 2001). TAXI I preferably inhibits xylanases with high and low values of pI and TAXI-II inhibits only xylanases with high pI values (Goesaert et al., 2003). TAXI-I and TAXI-II have pI values of 8.8 and 9.3, respectively (Debyser et al., 1999).

All isoforms of TAXI-I inhibit xylanases from Aspergillus niger and Bacillus subtilis belong to the family of GH11 but TAXI-II only inhibits bacterial xylanases from the 
same GH family. These forms are the products of similar genes or the results of post-translational modification. Isoforms of inhibitors encoded by different genes were called TAXI-IA, TAXI-IB, TAXI-IIA and TAXI-IIB. Nucleotide sequence of TAXI-I does not contain introns, and G/C nucleotides form $68 \%$ of total nucleotides (Fierens et al., 2003). Sansen et al. (2004) found that TAXI-I is composed of 6 disulfide bridges. The similarity of TAXI-II with other known proteins is negligible to the carbohydrate-derived glycoproteins (Gebruers et al., 2001).

The specific taxi-III and taxi-IV genes were identified in wheat (Igawa et al., 2004), but Raedschelders et al. (2004) considered that the TAXI-III and TAXI-IV proteins encoded by these genes are TAXI-I and TAXI-II isoforms because they have 99.6 and $99.8 \%$ similarity to TAXI-IB and TAXI-IIB, respectively. Protein inhibitors similar to the structure and properties of TAXI-I and TAXI-II have also been found in other cereals, namely rye, durum wheat and barley. The properties are very similar and typical for TAXI-like proteins, with molecular weight of $40 \mathrm{kDa}$ and alkaline pI value (> 8.5) (Goesaert et al., 2001; Goesaert et al., 2002; Goesaert et al. 2003).

3D structure of TAXI is similar to pepsine-like aspartate peptidases (Sansen et al., 2004; Dornez et al., 2010) but has no proteolytic activity. TAXI protein consists of two $\beta$-barrel domains with several helical segments divided by an extended cleft (Dornez et al., 2010). TAXI inhibitor binds at the active site of xylanase, resulting in competitive inhibition of the enzyme (Tundo et al., 2015). TAXI-I was able to inhibit recombinant xylanase from Penicillium funiculosum (GH11) although it did not inhibit recombinant xylanase from P. occitanis (GH11). The inability of the inhibition of GH11 xylanase can be explained by the lack of twenty amino acids in the thumb of recombinant xylanase resulting in steric clashes (Driss et al., 2013).

Recombinant TAXI inhibitor was successfully produced by E. coli and P. pastoris (Fierens et al., 2004). Similar biochemical properties were measured for rTAXI-I expressed in both E. coli and P. pastoris and natural TAXI-I, although the pI value of rTAXI-I was higher (9.3) than the pH value of natural TAXI-I (8.8). Fierens et al. (2004) confirmed that rTAXI and natural TAXI can inhibit bacterial and fungal GH11 xylanases while GH10 xylanases were not inhibited. rTAXI expressed in P. pastoris was glycosylated but this had no effect on xylanase inhibitory activity.

The presence of TAXI inhibitors is significantly affected under stress conditions, specifically by pathogen infection (Gebruers et al., 2002; Moscetti et al., 2013). As mentioned above, it seems that XIs play a key role in plant defence (Elliot et al., 2009; Bellincampi et al., 2014). Moscetti et al. (2013) proved that wheat trans- genic plants with over-expression of TAXI-III limited F. graminearum infection. Igawa et al. (2004) observed over-expression of TAXI-IB/III and TAXI-IIB/IV in wheat leaves after the infection by the fungus Blumeria graminis. Tundo et al. (2015) confirmed the dual function of XIs, namely TAXI-III and XIP. These proteins competitively inhibited F. graminearum xylanase activity (GH11) and also prevented host cell death activities caused by xylanases. Based on these data, TAXI is a potential representative of a new class of plant proteins whose function is to protect plants from the xylanase effects (Sun et al., 2018).

\subsection{TLXI}

TLXI and TLXI-like proteins were identified in wheat, rye and durum wheat (Fierens et al., 2007; Dornez et al., 2010). The inhibitor is a small variously glycosylated protein with molecular weight of $18-21 \mathrm{kDa}$ and alkaline $\mathrm{pI}(\geq 9.3)$. The inhibitor is named as tautine-like proteins due to its highly homologous amino acid sequence (more than 60\%) with these proteins (Fierens et al., 2007; Rombouts et al., 2009). Although XIP and TAXI belong to competitive XIs, TLXI is a non-competitive inhibitor of the GH11 family xylanases. The inhibitory effect of TLXI on xylanases of the GH10 family was not described (Fierens et al., 2007).

The 3D structure of TLXI contains two domains. The first domain is a $\beta$-sandwich built up of $\beta$ strands and the second domain consists of $\beta$-hairpin turn followed by an extended loop with His-22. This residue, key for inhibitory activity, interacts with the negatively charged residue located at the thumbs or on the fingers of the GH11 xylanases (Dornez et al., 2010). Vandermarliere et al. (2009) suggested that the whole loop region might be involved in inhibitory activity of TLXI. The gene sequence of $t$ txi consists of 177 amino acids and no introns. The signal sequence encodes 26 amino acids followed by 151-amino acid mature protein. TLXI have one glycosylation site at Asn-95 in which glycans of different compositions were detected. TLXI contains ten cysteine residues involving in five intramolecular disulfide bridges. Due to this conformation, TLXI xylanase inhibitor is more stable at extreme $\mathrm{pH}$ and temperature (Fierens et al., 2007).

Inhibition of the TLXI inhibitor has been described in a number of different xylanases. TLXI strongly inhibits xylanase isolated from Trichoderma longibrachiatum, similar to xylanases produced by the filamentous fungi A. niger, Trichoderma viride and P. funiculosum or bacteria Thermobacillus xylanilyticus and B. subtilis. TLXI preferentially inhibits acidic xylanases (Fierens et al., 2007). The inhibition rate of TLXI xylanases depends on temperature and $\mathrm{pH}$, maximum inhibitory activity was observed at pH 5.0 and $40{ }^{\circ} \mathrm{C}$ (Fierens et al., 2009). 
The recombinant TLXI expressed in P. pastoris resulting in a $21 \mathrm{kDa}$ protein retains biological activity but its inhibitory activity was lower than that of the native protein (Fierens et al., 2007). Although this protein has been discovered in 2007 (Fierens et al., 2007), little information exists about its specificity as well as its involvement in plant defence to stress conditions.

\section{Conclusion}

Insufficient quality of cereal grains has a negative impact on consumer health. It seems that XIs can be a suitable tool for cereal grain defence to pathogenesis and accumulation of mycotoxins. XIP and TAXI type of XIs belong to potential candidates to prevent infection due to the inhibition of bacterial and fungal xylanases from the GH10 and GH11 families. The response of plants to stress factors or the tools of recombinant techniques of DNA can be used for increasing of XI production. This can lead to improved plant defence to pathogens. Plant-derived xylanases can be an appropriate alternative to currently used microbial xylanases in cereal processing because no inhibitory effect of XIs on their activities was observed.

\section{Acknowledgment}

This work was supported by the grants of APPV-16-0088 and APVV-14-0393.

\section{References}

Bellincampi, D., Cervone. F., Lionetti, V., 2014: Plant cell wall dynamics and wall-related susceptibility in plant-pathogen interactions. Front. Plant Sci., 5: e228. https://doi.org/10.3389/fpls.2014.00228

Bonnin, E., Daviet, S., Gebruers, K., Delcour, J.A., Goldson, A., Juge, N., Saulnier, L., 2005: Variation in the levels of the different xylanase inhibitors in grain and flour of 20 French wheat cultivars. J. Cereal Sci., 41(3): 375-379. https://doi.org/10.1016/j.jcs.2004.11.001

Brutus, A., Reca, I.B., Herga, S., Mattei, B., Puigserver, A., Chaix, J.C., Juge, N., Bellincampi, D., Giardina, T., 2005. A family 11 xylanase from the pathogen Botrytis cinerea is inhibited by plant endoxylanase inhibitors XIP-I and TAXI-I. Biochem. Biophy. Res. Commun., 337: 160-166. https://doi.org/10.1016/j.bbrc.2005.09.030

Caspers, M.P.M, Lok, F., Sinjorgo, K.M.C., van Zeijl, M.J., Nielsen, K.A., Cameron-Mills, V., 2001: Synthesis, processing and export of cytoplasmic endo-beta-1,4-xylanase from barley aleurone during germination. Plant J., 26: 191-204. https://doi.org/10.1046/j.09607412.2001.01019.x

Chang, H.-X., Yendrek, C. R., Caetano-Anolles, G., Hartman, G. L., 2016: Genomic characterization of plant cell wall degrading enzymes and in silico analysis of xylanases and polygalacturonases of Fusarium virguliforme. BMC Microbiol., 16(1): e147. https://doi.org/10.1186/ s12866-016-0761-0
Croes, E., Gebruers, K., Luyten, N., Delcour, J.A., Courtin, C.M., 2009a: Immunoblot quantification of three classes of proteinaceous xylanase inhibitors in different wheat (Triticum aestivum) cultivars and milling fractions. J. Agric. Food Chem., 57(3):1029-1035. https://doi. org/10.1021/jf802638n

Croes, E., Gebruers, K., Luyten, N., Delcour, J.A., Courtin, C.M., 2009b: The three classes of wheat xylanase-inhibiting proteins accumulate in an analogous way during wheat ear development and germination. J. Plant Physiol., 166(12): 1253-1262. https://doi.org/10.1016/j.jplph.2009.02.008

Debyser, W., Derdelinck, G., Delcour, J.A., 1997: Arabinoxylan solubilisation and inhibition of the barley malt xylanolytic system by wheat during brewing with wheat wholemeal adjunct: evidence for a new class of enzyme inhibitors. J. Am. Soc. Brew. Chem., 55(1): 153-156. https://doi.org/10.1094/ASBCJ-55-0153

Debyser, W., Peumans, W.J., Van Damme, E.J.M., Delcour, J.A., 1999: Triticum aestivum xylanase inhibitor (TAXI), a new class of enzyme inhibitor affecting breadmaking performance. J. Cereal Sci., 30(1): 39-43. https://doi.org/10.1006/jcrs.1999.0272

Dornez, E., Croes, E., Gebruers, K., Coninck, B.D., Cammue, B.P.A., Delcour, J.A., Courtin, C.M., 2010: Accumulated evidence substantiates a role for three classes of wheat xylanase inhibitors in plant defense. Crit. Rev. Plant Sci., 29(4): 244-264. https://doi.org/10.1080/07352689 .2010 .487780

Dornez, E., Gebruers, K., Joye, I.J., De Ketelaere, B., Lenartz, J., Massaux, C., Bodson, B., Delcour, J.A., Courtin, C.M., 2008: Effects of genotype, harvest year and genotype-by-harvest year interactions on arabinoxylan, endoxylanase activity and endoxylanase inhibitor levels in wheat kernels. J. Cereal Sci., 47: 180-189. https://doi.org/10.1016/j.jcs.2007.03.008

Dornez, E., Gebruers, K., Wiame, S., Delcour, J.A., Courtin, C.M., 2006: Insight into the distribution of arabinoxylans, endoxylanases, and endoxylanase inhibitors in industrial wheat roller mill streams. J. Acric. Food Chem., 54(22): 8521-8529. https://doi.org/10.1021/jf061728n

Dornez, E., Verjans, P., Arnaut, F., Delcour, J. A., Courtin, C. M., 2011: Use of psychrophilic xylanases provides insight into the xylanase functionality in bread making. J. Agr. Food Chem., 59(17): 9553-9562. https://doi.org/10.1021/jf201752g

Driss, D., Berrin, J.G., Juge, N., Bhiri, F., Ghorbel, R., Chaabouni, S.E., 2013: Functional characterization of Penicillium occitanis Pol6 and Penicillium funiculosum GH11 xylanases. Protein Expr. Purif., 90(2): 195201. https://doi.org/10.1016/j.pep.2013.06.007

Drouillard, S., Armand, S., Davies, G.J., Vorgias, C.E., Henrissat, B., 1997: Serratia marcescens chitobiase is a retaining glycosidase utilizing substrate acetamido group participation. Biochem. J., 328(3): 945949. https://doi.org/10.1042/bj3280945

Egi, A., Speers, R. A., Schwarz, P. B., 2004: Arabinoxylans and their behavior during malting and brewing. Tech. Quart. Mast. Brew. Assoc. Am., 41: $248-267$

Elliot, G., Durand, A., Hughes, R.K., Kroon, P.A., D’Ovidio, R., Juge, N, 2009: Isolation and characterisation of a xylanase inhibitor Xip-II gene from durum wheat. J. Cereal Sci., 50(3): 324-331. https://doi. org/10.1016/j.jcs.2009.06.013

Elliot, G.O., Hughes, R.K., Juge, N., Kroon, P.A., Williamson, G., 2002: Functional identification of the cDNA coding for a wheat endo-1,4-beta-D-xylanase inhibitor. FEBS Lett., 519(1-3): 66-70. https://doi. org/10.1016/S0014-5793(02)02710-2

Evers, T., Millar, S., 2002: Cereal grain structure and development: some implications for quality. J. Cereal Sci., 37: 187-194.

Fierens, E., Rombouts, S., Gebruers, K., Goesaert, H., Brijs, K., Beaugrand, J., Volckaert, G., Van Campenhout, S., Proost, P., Courtin, C.M., Delcour, J.A., 2007: TLXI, a novel type of xylanase inhibitor from wheat (Triticum aestivum) belonging to the thaumatin family. Biochem. J., 403(3): 583-591. https://doi.org/10.1042/BJ20061291 
Fierens, K., Brijs, K., Courtin, C. M., Gebruers, K., Goesaert, H., Raedschelders, G., Robben, J., Van Campenhout, S., Volckaert, G., Delcour, J.A., 2003: Molecular identification of wheat endoxylanase inhibitor TAXI-I1, member of a new class of plant proteins. FEBS Letters, 540(1-3): 259263. https://doi.org/10.1016/S0014-5793(03)00276-X

Fierens, K., Gebruers, K., Voet, A.R., De Maeyer, M., Courtin, C.M., Delcour, J.A., 2009: Biochemical and structural characterization of TLXI, the Triticum aestivum L. thaumatin-like xylanase inhibitor. J. Enzyme Inhib. Med. Chem., 24(3): 646-654. https://doi.org/10.1080/14756360802321831

Fierens, K., Geudens, N., Brijs, K., Courtin, C.M., Gebruers, K., Robben, J., Campenhout, S.V., Volckaert, G., Delcour, J.A., 2004: High-level expression, purification, and characterization of recombinant wheat xylanase inhibitor TAXI-I secreted by the yeast Pichia pastoris. Protein Expr. Purif., 37(1): 39-46. https://doi.org/10.1016/j. pep.2004.05.014

Flatman, R., McLauchlan, W.R., Juge, N., Furniss, C., Berrin, J.G., Hughes, R.K., Ladbury, J.E., O’Brien, R., Williamson, G., 2002: Interactions defining the specificity between fungal xylanases and the xylanase-inhibiting protein XIP-I from wheat. Biochem. J., 365(3): 773-781. https://doi.org/10.1042/bj20020168

Frederix, S.A., Van Hoeymissen, K.E., Courtin, C.M., Delcour, J.A., 2004: Water-extractable and water-unextractable arabinoxylans affect gluten agglomeration behavior during wheat flour gluten starch separation. J. Agric. Food Chem., 52(26): 7950-7956. https://doi.org/10.1021/ jf049041v

Furniss, C.S., Belshaw, N.J., Alcocer, M.J., Williamson, G., Elliott, G.O., Gebruers, K., Haigh, N.P., Fish, N.M., Kroon, P.A., 2002: A family 11 xylanase from Penicillium funiculosum is strongly inhibited by three wheat xylanase inhibitors. Biochim. Biophys. Acta, 1598(1-2): 24-29. https://doi.org/10.1016/S0167-4838(02)00366-7

Gebruers, K., Brijs, K., Courtin, C.M., Fierens, K., Goesaert, H., Rabijns, A., Raedschelders, G., Robben, J., Sansen, S., Sørensen, J.F., Van Campenhout, S., Delcour, J.A., 2004: Properties of TAXI-type endoxylanase inhibitors. Biochim. Biophys. Acta., 1696(2): 213-221. https://doi. org/10.1016/j.bbapap.2003.08.013

Gebruers, K., Debyser, W., Goesaert, H., Proost, P., Van Damme, J., Delcour, J.A., 2001: Triticum aestivum L. endoxylanase inhibitor (TAXI) consists of two inhibitors, TAXI I and TAXI II, with different specificities. Biochem. J., 353(2): 239-244. https://doi.org/10.1042/ bj3530239

Gebruers, K., Goesaert, H., Brijs, K., Courtin, C.M., Delcour, J.A., 2002: Purification of TAXI-like endoxylanase inhibitors from wheat (Triticum aestivum L.) whole meal reveals a family of isoforms. J. Enzyme Inhib. Med. Chem., 17(1): 61-68. https://doi. org/10.1080/14756360290018611

Goesaert, H., Debyser, W., Gebruers, K., Proost, P., Van Damme, J., Delcour, J. A., 2001: Purification and partial characterization of an endoxylanase inhibitor from barley. Cereal Chem. J., 78(4): 453-457. https:// doi.org/10.1094/CCHEM.2001.78.4.453

Goesaert, H., Elliott, G., Kroon, P.A., Gebruers, K., Courtin, C.M., Robben, J., Delcour, J.A., Juge, N., 2004: Occurrence of proteinaceous endoxylanase inhibitors in cereals. Biochim. Biophys. Acta, 1696(2): 193202. https://doi.org/10.1016/j.bbapap.2003.08.015

Goesaert, H., Gebruers, K., Brijs, K., Courtin, C.M., Delcour, J.A., 2003: TAXI type endoxylanase inhibitors in different cereals. J. Agric. Food Chem., 51(13): 3770-3775. https://doi.org/10.1021/jf0262155

Goesaert, H., Gebruers, K., Courtin, C.M., Proost, P., Van Damme, J., Delcour, J.A., 2002: A family of 'TAXI'-like endoxylanase inhibitors in rye. J. Cereal Sci., 36(2): 177-185. https://doi.org/10.1006/jcrs.2002.0462

Gusakov, A. V., 2010: Proteinaceous inhibitors of microbial xylanases. Biochem. (Moscow), 75(10): 1185-1199. https://doi.org/10.1134/ S0006297910100019
Hou, C., Lv, T., Zhan, Y., Peng, Y., Huang, Y., Jiang, D., Weng, X., 2014: Overexpression of the RIXI xylanase inhibitor improves disease resistance to the fungal pathogen, Magnaporthe oryzae, in rice. Plant Cell Tissue Organ Cult., 120(1): 167-177. https://doi.org/10.1007/s11240-014-0590-5

Hou, C.-X., Zhan, Y.-H., Jiang, D.-A., Weng, X.-Y., 2013: Functional characterization of a new pathogen induced xylanase inhibitor (RIXI) from rice. Eur. J. Plant Pathol., 138(2): 405-414. https://doi.org/10.1007/ s10658-013-0342-0

Huo, W.K., Liu, M.Q., Weng, X.Y., Qi, Y.P., 2018: Recombinant rice xylanase inhibitor (RIXI) expressed in Escherichia coli and its inhibitory activity on family GH11endo-xylanases. Int. J. Biolog. Macromol., 117(1): 1343-1351. https://doi.org/10.1016/j.ijbiomac.2017.11.177

Igawa, T., Ochiai-Fukuda, T., Takahashi-Ando, N., Ohsato, S., Shibata, T., Yamaguchi, I., Kimura, M., 2004: New TAXI-type xylanase inhibitor genes are inducible by pathogens and wounding in hexaploid wheat. Plant Cell Physiol., 45(10): 1347-1360. https://doi.org/10.1093/pcp/pch195

Juge, N., Payan, F., Williamson, G., 2004: XIP-I, a xylanase inhibitor protein from wheat: a novel protein function. Biochim. Biophys. Acta, 1696(2): 203-211. https://doi.org/10.1016/j.bbapap.2003.08.014

Krogh Madsen, C., Pettersson, D., Hjortshøj, R., Katholm, A., Brinch-Pedersen, H., 2018: Superior growth rates in broilers fed wheat with low in vitro feed-xylanase inhibition. J. Agr. Food Chem., 66(16): 40444050. https://doi.org/10.1021/acs.jafc.8b00208

Lin, P., Wong, J.H., Ng, T.B., Ho, V.S.M., Xia, L., 2013: A sorghum xylanase inhibitor-like protein with highly potent antifungal, antitumor and HIV-1 reverse transcriptase inhibitory activities. Food Chem., 141(3): 2916-2922. https://doi.org/10.1016/j.foodchem.2013.04.013

Liu, X., Zhang, Y., Wei, Z., Chen, H., Jia, X., 2017: Molecular cloning and characterizations of xylanase inhibitor protein from wheat (Triticum aestivum). J. Food Sci., 82(7), 1582-1587. https://doi. org/10.1111/1750-3841.13773

McLauchlan, W.R., Garcia-Conesa, M.T., Williamson, G., Roza, M., Ravestein, P., 1999: A novel class of protein from wheat which inhibits xylanases. Biochem. J., 338(2): 441-446. https://doi.org/10.1042/bj3380441

Mendis, M., Ohm, J.-B., Delcour, J. A., Gebruers, K., Meinhardt, S., Simsek, S., 2013: Variability in arabinoxylan, xylanase activity, and xylanase inhibitor levels in hard spring wheat. Cereal Chem. J., 90(3): 240-248. https://doi.org/10.1094/CCHEM-08-12-0103-R

Moscetti, I., Tundo, S., Janni, M., Sella, L., Gazzetti, K., Tauzin, A., Giardina, T., Masci, S., Favaron, F., D'Ovidio, R., 2013: Constitutive expression of the xylanase inhibitor TAXIIII delays Fusarium head blight symptoms in durum wheat transgenic plants. Mol. Plant Microbe Interact., 26(12): 1464-1472. https://doi.org/10.1094/MPMI-04-13-0121-R

Paper, J.M., Scott-Craig, J.S., Adhikari, N.D., Cuomo, C.A., Walton, J.D., 2007: Comparative proteomics of extracellular proteins in vitro and in planta from the pathogenic fungus Fusarium graminearum. Proteomics, 7(17):3171-3183. https://doi.org/10.1002/pmic.200700184

Payan, F., Leone, P., Porciero, S., Furniss, C., Tahir, T., Williamson, G., Durand, A., Manzanares, P., Gilbert, H.J., Juge, N., Roussel, A., 2004: The dual nature of the wheat xylanase protein inhibitor XIP-I: structural basis for the inhibition of the family 10 and family 11 xylanases. J. Biol. Chem., 279(34): 36029-36037. https://doi.org/10.1074/jbc.M404225200

Raedschelders, G., Debefve, C., Goesaert, H., Delcour, J.A., Volckaert, G., Van Campenhout, S., 2004: Molecular identification and chromosomal localization of genes encoding Triticum aestivum xylanase inhibitor I-like proteins in cereals. Theor. Appl. Genet., 109(1): 112-121. https://doi.org/10.1007/s00122-004-1601-4

Rombouts, S., Fierens, E., Vandermarliere, E., Voet, A., Gebruers, K., Beaugrand, J., Courtin, C.M., Delcour, J.A., de Maeyer, M., Rabijns, A., Van Campenhout, S., Volckaert, G., 2009: His22 of TLXI plays a critical role in the inhibition of glycoside hydrolase family 11 xylanases. J. Enzyme Inhib. Med. Chem., 24(1): 38-46. https://doi.org/10.1080/14756360701841913 
Rouau, X., Surget, A., 1998. Evidence for the presence of a pentosanase inhibitor in wheat flours. J. Cereal Sci., 28(1): 63-70. https://doi. org/10.1006/jcrs.1997.0180

Sancho, A.I., Faulds, C.B., Svensson, B., Bartolomé, B., Williamson, G., Juge, N., 2003: Cross-inhibitory activity of cereal protein inhibitors against $\alpha$-amylases and xylanases. Biochim. Biophys. Acta, 1650(1-2): 136-144. https://doi.org/10.1016/S1570-9639(03)00209-7

Sansen, S., De Ranter, C.J., Gebruers, K., Brijs, K., Courtin, C.M., Delcour, J.A., Rabijns, A., 2004: Structural basis for inhibition of Aspergillus niger xylanase by Triticum aestivum xylanase inhibitor-I. J. Biol. Chem., 279(34): 36022-36028. https://doi.org/10.1074/jbc.M404212200

Saulnier, L., Sado, P.E., Branlard, G., Charmet, G., Guillon, F., 2007: Wheat arabinoxylans: Exploiting variation in amount and composition to develop enhanced varieties. J. Cereal Sci., 46(3): 261-281. https:// doi.org/10.1016/j.jcs.2007.06.014

Selvaraj, T., Kim, S.K., Kim, Y.H., Jeong, Y.S., Kim, Y.J., Phuong, N.D., Jung, K.H., Kim, J., Yun, H.D., Kim, H., 2010: The role of carbohydrate-binding module (CBM) repeat of a multimodular xylanase (XynX) form Clostridium thermocellum in cellulose and xylan binding. J. Microbiol., 48: 856-861. https://doi.org/10.1007/s12275-010-0285-5

Simpson, D.J., Fincher, G.B., Huang, A.H.C., Cameron-Mills, V., 2003: Structure and function of cereal and related higher plant (1 4)-beta-xylan endohydrolases. J. Cereal Sci., 37(2): 111-127. https://doi. org/10.1006/jcrs.2002.0488

Simsek, S., Ohm, J.B, 2009: Structural changes of arabinoxylans in refrigerated dough. Carbohydr. Polym., 77(1): 87-94. https://doi. org/10.1016/j.carbpol.2008.12.012

Smeets, N., Nuyens, F., Niewold, T., Van Campenhout, L., 2014: Temperature resistance of xylanase inhibitors and the presence of grain-associated xylanases affect the activity of exogenous xylanases added to pelleted wheat-based feeds. Cereal Chem. J., 91(6): 572-577. https://doi.org/10.1094/CCHEM-02-14-0032-R

Sonah, H., Chavan, S., Katara, J., Chaudhary, J., Kadam, S., Patil, G., Deshmukl, R., 2016: Genome-wide identification and characterization of xylanase inhibitor protein (XIP) genes in cereals. Indian J. Genet., 76(2): 159-166. https://doi.org/10.5958/0975-6906.2016.00036.5
Sun, R.J., Xu, Y., Hou, C.X., Zhan, Y.H., Liu, M.Q., Weng, X.Y., 2018: Expression and characteristics of rice xylanase inhibitor OsXIP, a member of a new class of antifungal proteins. Biol. Plant., 62(3):569-578. https://doi.org/10.1007/s10535-018-0787-2

Takahashi-Ando, N., Inaba, M., Ohsato, S., Igawa, T., Usami, R., Kimura, M., 2007: Identification of multiple highly similar XIP-type xylanase inhibitor genes in hexaploid wheat. Biochem. Biophys. Res. Commun., 360(4): 880-884. https://doi.org/10.1016/j.bbrc.2007.06.151

Terwisscha can Scheltinga, A.C., Hennig, M., Dijkstra, B.W., 1996: The 1.8 Å resolution structure of hevamine, a plant chitinase/lysozyme, and analysis of the conserved sequence and structure motifs of glycosyl hydrolase family 18. J. Mol. Biol., 262(2): 243-257. https://doi. org/10.1006/jmbi.1996.0510

Tundo, S., Moscetti, I., Faoro, F., Lafond, M., Giardina, T., Favaron, F., Sella, L., D’Ovidio,R., 2015: Fusarium graminearum produces different xylanases causing host cell death that is prevented by the xylanase inhibitors XIP-I and TAXI-III in wheat. Plant Sci., 240: 161-169. https://doi.org/10.1016/j.plantsci.2015.09.002

Vandermarliere, E., Lammens, W., Schoepe, J., Rombouts, S., Fierens, E., Gebruers, K., Volckaert, G., Rabijns, A., Delcour, J.A., Strelkov, S.V., Courtin, C.M., 2010: Crystal structure of the noncompetitive xylanase inhibitor TLXI, member of the small thaumatin-like protein family. Proteins: Struct., Funct., Bioinf., 78(10): 2391-2394. https://doi. org/10.1002/prot.22737

Wu, S.C., Ham, K.S., Darvill, A.G., Albersheim, P., 1997: Deletion of two endo-beta-1,4-xylanase genes reveals additional isozymes secreted by the rice blast fungus. Mol. Plant Microbe Interact., 10(6): 700-708. https://doi.org/10.1094/MPMI.1997.10.6.700

Zhan, Y., Sun, R., Sun, X., Xu, Y., Hou, C., Huang, Y., Jiang, D., Weng, X., 2017a: Expression regulation of a xylanase inhibitor gene riceXIP in rice (Oryza sativa L.). Braz. J. Bot., 40 (4): 983-991. https://doi. org/10.1007/s40415-017-0400-5

Zhan, Y., Sun, X., Rong, G., Hou, C., Huang, Y., Jiang, D., Weng, X., 2017b: Identification of two transcription factors activating the expression of OsXIP in rice defence response. BMC Biotechnol., 17(1): e26. https://doi.org/10.1186/s12896-017-0344-7 